\title{
MANAJEMEN STRATEGIK DAN MANAJEMEN OPERASIONAL SERTA IMPLEMENTASINYA PADA LEMBAGA PENDIDIKAN
}

\author{
MAPPASIARA \\ Fakultas Tarbiyah dan Keguruan UIN Alauddin Makassar \\ Jl. HM. Yasin Limpo No. 36 Makassar \\ Email: mappasiara_mappa@yahoo.co.id
}

\begin{abstract}
:
Education is a long-term investment in designing the pattern of human life in the future. First, education as an effort oriented to the formation of a potential human figure intellectually through the learning process; Secondly, education is an ethnically and ethnically formative society through the transfer of values process contained therein; Third, education is one of the guarantees to gain a better life as well as high dignity. In order for education to be an investment then the development and dynamics of educational institutions to a better direction is a necessity. One of the theoretical concepts offered in this paper is the implementation of strategic management and operational management in educational institutions. Through these two theoretical concepts, management of educational institutions is expected to direct and influence the quality of education products / outcomes such as curriculum, administration of institutional management and students.
\end{abstract}

Keywords: Strategic Management, Operational Management, Educational Institutions

\section{PENDAHULUAN}

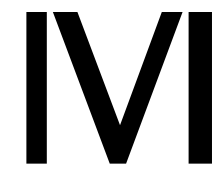

utu pendidikan merupakan salah satu tema sentral yang menyedot perhatian dalam berbagai diskusi kependidikan di Indonesia selama ini. Tema ini semakin menarik manakala dihubungkan dengan lunturnya nilai-nilai moralitas dan persaingan global memasuki milenium ketiga ini.

Paradigma globalisasi sebagai produk kemajuan sains dan teknologikhususnya teknologi informasi-sebagai bentuk kelanjutan modernisasi (Azizi, 2003: viii). Akbar S. Ahmed dan Hastings Donnan juga menggambarkan globalisasi sebagai era yang secara substansial mengacu kepada perkembangan yang sangat cepat dalam bidang teknologi, komunikasi, transformasi dan informasi yang mampu mengantarkan bagian-bagian dunia yang jauh menjadi sesuatu hal bisa dijangkau dengan mudah (Ahmed dan Hastings Donnan, 1994: 1).

Fenomena globalisasi, dalam pandangan A. Qodri Azizy berpendapat bahwa globalisasi secara simultan terus menimbulkan dua dimensi kehidupan yaitu berbentuk tantangan dan ancaman. Dimensi yang berbentuk tantangan adalah segala dampak positif dari fenomena globalisasi, sehingga mampu menciptakan berbagai fasilitas dan kemudahan dalam berbagai aktivitas manusia, termasuk untuk kepentingan pendidikan Islam. Dimensi yang berwujud ancaman adalah 
seluruh dampak negatif yang ditimbulkan dari fenomena globalisasi bagi perkembangan dan peradaban manusia dan masyarakat luas, misalnya makin kuatnya pola hidup yang materialistik, hedonistik bahkan sekuleristik (Azizy, 2003: 23-24). Dalam kondisi yang demikian, fungsi dan peran pendidikan Islam harus dimaksimalkan dalam rangka upaya melestarikan, mengembangkan dan mewariskan cita-cita masyarakat madani (Nata, 2003: 83). Dari fenomena inilah, maka seluruh upaya yang diperkirakan dapat meminimalisir dampak negatif minimal mampu menfilter - berbagai dampak negatif tersebut terus dilakukan secara sistematis dan berkesinambungan.

Pendidikan merupakan suatu investasi terbesar (the best of investation) dalam merancang pola kehidupan manusia ke depan. Sebab dengan modal pendidikan, manusia memiliki tiga keuntungan. Pertama, pendidikan sebagai upaya yang berorientasi pada pembentukan sosok manusia yang potensial secara intelektual melalui proses pembelajaran (intellectual oriented by transfer of knowledge); Kedua, pendidikan merupakan upaya pembentukan masyarakat yang berwatak, beretika dan berestetika melalui transfer of values process yang terkandung di dalamnya; Ketiga, pendidikan merupakan salah satu jaminan untuk memperoleh kehidupan yang lebih baik sekaligus kemartabatan yang tinggi (Q.S. AIMujadalah: 11), baik secara material maupun transcendental. Melalui pemahaman inilah, pendidikan secara otomatis menempati posisi yang sangat sentral dan strategis dalam membangun kehidupan manusia ke depan yang berkualitas dan seimbang.

Namun demikian, ada beberapa faktor yang dapat diterapkan oleh lembaga pendidikan sehingga kualitas output pendidikan dapat memenuhi harapan masyarakat, yaitu manusia yang berilmu pengetahuan dan teknologi serta memiliki iman yang tinggi. Untuk mencapai harapan masyarakat dan menunjang tujuan pendidikan yang telah ditetapkan oleh pemerintah diperlukan implementasi manajemen strategik dan manajemen operasional dalam pengelolaan lembaga pendidikan.

Untuk meningkatkan kualitas lembaga pendidikan, pengelolaan pendidikan harus dikelola dan disentuh secara professional dan fungsional sesuai tuntutan dunia kemanajemenan, artinya berbagai sumber daya yang mempengaruhi terjadinya seluruh proses pendidikan perlu ditangani secara terencana, terorganisir, terarah dan terkendali. Dari konteks inilah maka lembaga pendidikan dituntut memiliki kompetensi manajerial yakni kemampuan membangun pola kerja yang sistematis, logis, realistis dan strategis.

Berdasarkan uraian di atas, penulis merumuskan masalah pokok tentang :

Manajemen strategik dan manajemen operasionalserta implementasinya

\section{Kajian Teoritis}


Manajemen secara etimologi berasal dari bahasa Inggris to manage yang berarti memerintah, mengatur, mengurus, mengemudikan. Kemudian dalam perkembangannya, kata to manage mengalami perubahan menjadi manajement yang berarti pimpinan, pengurusan dan pengelolaan (Willy dkk., 1997: 319). Dalam bahasa Arab, kata manajemen identik dengan tadbir (تدبير), idarah (إدارة) yang berarti mengelola, pengelolaan (Alkalali, 1987: 247-248). Term manajemen dalam aplikasinya sering diartikan sama dengan administrasi, termasuk dalam dunia pendidikan. Alasan mereka menyamakan keduanya dengan dasar bahwa secara fungsional dan operasional. Memang harus diakui bahwa para ahli hingga kini belum ada kesepakatan dalam dua hal itu, namun demikian ada juga yang berpendapat bahwa manajemen dan administrasi merupakan dua hal yang berbeda sebab manajemen merupakan inti dari administrasi (Burhanuddin, 1994: 30-31).

Apabila ditelusuri dalam berbagai literatur manajemen, maka pengertian manajemen secara terminologis akan ditemukan bahwa manajemen mengandung empat pengertian, yaitu: (a) manajemen sebagai suatu ilmu, (b) manajemen sebagai suatu proses, (c) manajemen sebagai suatu seni (art) atau kiat, (d) manajemen sebagai suatu profesi atau kemampuan. Namun demikian, secara sederhana manajemen dapat didefinisikan sebagai upaya untuk mendapatkan sesuatu yang dikerjakan melalui orang lain (get things done through other people)

Strategik menurut etimologi berasal dari kata strategic (Inggris) yang berarti kiat, cara, taktik utama (Nawawi, 2003: 147). Secara historis kata strategik berawal dari dunia militer dan secara populer diartikan sebagai kiat yang digunakan oleh para komandan militer (jenderal) untuk memenangkan peperangan. Ralph Taylor dalam Websters's World University Dictionary mengemukakan "strategic mean of great or vital importance within an integrated whole" (Taylor, 1965: 989) Namun kata strategik, kemudian dipergunakan juga oleh hampir seluruh organisasi untuk menentukan pilihan dalam memenangkan "peperangan" tertentu guna mencapai tujuan (Siagian, 2001: 15).

Dari pengertian di atas, maka yang dimaksud manajemen strategik adalah serangkaian keputusan dan tindakan mendasar yang dibuat untuk manajemen puncak dan diimplementasikan oleh seluruh jajaran suatu organisasi dalam rangka pencapaian suatu tujuan organisasi tersebut. Definisi lain tentang manajemen strategik adalah usaha manajerial menumbuhkembangkan kekuatan organisasi untuk mengeksploitasi peluang yang muncul guna mencapai tujuan yang telah ditetapkan sesuai misi yang telah ditetapkan (Nawawi, 2003: 148). Kemudian R. Edward Freeman mendefinisikan manajemen strategik adalah suatu proses terus menerus dan walaupun pada waktunya harus dipilih titik-titik yang berlainan dengan maksud untuk mengambil keputusan dalam rangka mencapai tujuan (Edward Freeman, 1996: 97). 
Berdasarkan beberapa definisi di atas, maka penulis dapat mengemukakan bahwa yang dimaksud manajemen strategik adalah serangkaian usaha, kiat, keputusan dan tindakan yang mendasar yang digariskan oleh pimpinan organisasi dan diimplementasikan oleh seluruh jajarannya dalam rangka mencapai tujuan yang telah ditetapkan oleh organisasi itu.

Flippo mengemukakan yang dimaksud dengan manajemen operasional meliputi pengelolaan dalam aspek pengadaan tenaga kerja (procurement), pengembangan (development), kompensasi, integrasi, (integration), pemeliharaan (maintenance) dan pemutusan hubungan kerja (separation). Manajemen operasional pada lembaga pendidikan merupakan kegiatan pelaksana yaitu kegiatan yang dilakukan oleh para personil pendidikan sesuai dengan tugas dan tanggungjawab yang dibebankan kepadanya, yang meliputi bidang-bidang kegiatan seperti bidang kurikulum, ketenagaan, keuangan, sarana dan prasarana, tata usaha dan humas.

\section{Implementasi Manajemen Strategik pada Lembaga Pendidikan}

Salah satu fungsi manajemen adalah perencanaan. Perencanaan dalam suatu organisasi atau lembaga pendidikan dibutuhkan adanya strategi atau yang disebut dengan perencanaan strategik (Renstra).

Perencanaan strategik disebut juga perencanaan jangka panjang. Strategi itu menurut R.G. Murdick J.E. Ross (1983) diartikan sebagai konfigurasi tentang hasil yang diharapkan tercapai pada masa depan. Dapat juga disebut konsepsi hari depan. Bentuk konfigurasi terungkap berdasarkan (1) ruang lingkup, (2) hasil persaingan, (3) target, dan (4) penataan sumber-sumber.

Pertama, ruang lingkup pendidikan menyangkut hasil-hasil pendidikan yang diharapkan, pemakai hasil pendidikan, pasarana hasil pendidikan, kualitas hasil dan karakteristik yang ditentukan untuk hasil pendidikan. Kedua, kemampuan hasil (produktivitas) pendidikan yang berkaitan dengan posisi suplai, pengelolaan yang spesifik dan kapasitas merenspons terhadap gerak perubahan. Ketiga, spesifikasi target-target yang menegaskan pernyataan kuantitatif target-target yang menegaskan pernyataan kuantitatif tujuan-tujuan yang akan dicapai, profitabilitas dan investasi beserta perkiraan resiko atau faktor penunjang lainnya. Keempat, penentuan sumber-sumber pendidikan menyangkut alokasi pengembangan sumber daya kependidikan, faktor geografik dan kecenderungan perubahan dengan perubahan yang berkenaan dengan sistem nilai. Sistem nilai itu akan memberi arah terhadap konsep, gagasan maupun praktik-praktik kependidikan (Fattah, 2008: 55-56).

Perencanaan strategik digunakan untuk mengatakan suatu lingkup perencanaan yang lebih "general".

Pengertian perencanaan strategik diungkapkan oleh Johnson Kast RozensWeig,sebagaimana dikutip Nanang Fatts yaitu proses penentuan sasaran utama, kebijaksanaan yang mengatur pengadaan dan pendayagunaan sumber-sumber 
serta strategi yang mengatur pengadaan dan pendayagunaan sumber untuk pencapaian tujuan. Langkah-langkah penyusunan rencana strategik, meliputi: (1) analisis keadaan sekarang dan akan datang; (2) identifikasi kekuatan dan kelemahan lembaga/organisasi; (3) mempertimbangkan norma-norma; (4) identifikasi kemungkinan dan resiko; (5) menentukan ruang lingkup hasil dan kebutuhan masyarakat; (6) menilai faktor-faktor penunjang; (7) merumuskan tujuan dan kriteria keberhasilan, dan (8) menetapkan penataan distribusi, sumbersumber (Fattah, 2008: 56).

Berkaitan dengan masalah di bidang pendidikan, konsep perencanaan strategik dapat diterapkan dalam perencanaan pendidikan. dengan perencanaan strategik, ada kecenderungan diperoleh suatu perumusan program yang lebih operasional. Berbagai faktor baik internal (organisasi) maupun eksternal (lingkungan) yang berpengaruh perlu diperhitungkan dalam proses perencanaan ini.

Oleh sebab itu penerapan pendekatan sistem perencanaan pendidikan yang strategik, bertujuan untuk mencari bentuk dan identitas pada masa yang akan datang dengan mempertimbangkan berbagai hubungan yang kompleks dalam suatu sistem. Satu hal yang dipertimbangkan mengenai pentingnya pendekatan sistem dalam renstra pendidikan disebabkan bahwa pendidikan itu merupakan suatu sektor kehidupan manusia yang kompleks atau suatu sistem yang kompleks. Hal ini dapat kita lihat bahwa berbicara masalah pendidikan tidak lepas dari berbagai faktor kehidupan lainnya, seperti: ekonomi, sosial, politik, kebudayaan, keamanan, dan sebagainya. Berbagai faktor tersebut perlu diperhitungkan dalam mengadakan renstra pendidikan. tanpa memperhatikan faktor-faktor tersebut beserta kecenderungannya, maka sulit dipertanggungjawabkan hasil proses perencanaan yang dilaksanakan.

Pendekatan sistem dalam renstra memberi dasar-dasar konseptual dalam perencanaan pendidikan, diharapkan dapat membantu dalam memecahkan masalah kependidikan yang kompleks tersebut. Pendekatan sistem sebagai suatu metode atau teknik analisis (system analysis) terutama berfungsi dalam hal memecahkan masalah atau pengambilan keputusan. Dalam hal ini sistem dikaitkan dengan metode ilmiah. Analisis sistem ini mencakup (1) menyadari adanya masalah; (2) mengidentifikasi variabel-variabel yang relevan; (3) menganalisis dan mensintesiskan faktor-faktor sehubungan dengan masalah yang dihadapi; (4) menentukan kesimpulan dalam bentuk program-program kegiatan. Dalam kaitan ini diaplikasikan paham sistem terhadap proses manajemen dalam wadah keorganisasian yang menjelaskan adanya suatu model umum dari sistem. Model umum dari suatu organisasi sebagai suatu sistem adalah adanya komponenkomponen masukan (input), transformasi, keluaran (output).

Dengan demikian, dapat disimpulkan pentingnya pendekatan sistem dalam renstra pendidikan berkaitan erat dengan usaha pemecahan masalah yang 
kompleks dengan cara mengenal esensi keterpaduan berbagai unsur sehingga proses yang diketahui benar-benar dapat menunjang pencapaian tujuan secara efektif dan optimal.

Untuk lebih melengkapi uraian pendekatan sistem ini, perlu dijelaskan mengenai arti sistem itu sendiri. Fitz Gerald (1981) mengartikan sistem sebagai jaringan kerja (network) prosedur yang saling berhubungan untuk melaksanakan aktivitas ke arah pencapaian tujuan yang spesifik. Dalam pencapaian tujuan khusus tersebut, metode pencapaian perlu dirinci, dikaitkan, dan disesuaikan dengan kondisi yang ada.

Berdasarkan hal di atas, metode penelaah dan pemecahan masalah didasarkan atas kerangka ini mempunyai ciri-ciri, sebagai berikut.

1. Sistematika dan sistemik (menyeluruh).

2. Berorientasi pada output atau konfigurasi keinginan.

3. Mempunyai tujuan menyeluruh.

4. Berdimensi jangka panjang, menengah, dan pendek.

5. Menerapkan metode keilmuan analisis teoretik dan empirik dengan program pengembangan.

6. Rencana operasional terjabar ke dalam proyek dan program

7. Berlandaskan kebijakan.

8. Memperhitungkan norma dan kaidah.

9. Mempunyai pada input, proses, output dengan informasi umpan balik (Fattah, 2008: 58).

Perencanaan strategi termasuk kategori perencanaan jangka panjang meliputi cakupan waktu di atas 10 tahun sampai dengan 25 tahun. Perencanaan ini mempunyai jangka menengah, lebih-lebih lagi jika dibandingkan dengan rencana jangka pendek. Semakin panjang rencana itu, semakin banyak variabel yang sulit dikontrol. Berdasarkan keriteria di atas, rencana pembangunan lima tahun (Repelita) dapat digolongkan ke dalam perencanaan jangka menengah.

Perencanaan jangka menengah mencakup kurun waktu pelaksanaan 5-10 tahun. Perencanaan ini penjabaran dari rencana jangka panjang, tetapi sudah lebih bersifat operasional.

\section{Implementasi Manajemen Operasional pada Lembaga Pendidikan.}

Perencanaan operasional memusatkan perhatian pada apa yang akan dikerjakan pada tingkat pelaksanaan di lapangan dari suatu rencana strategi. Perencanaan ini bersifat spesifik dan berfungsi untuk memberikan petunjuk konkret tentang bagaimana suatu program atau proyek khusus dilaksanakan menurut aturan, prosedur, dan ketentuan lain yang ditetapkan secara jelas sebelumnya. Itulah sebabnya rencana operasional ini telah dijabarkan dan diterjemahkan ke dalam data kuantitatif yang dapat diukur dan biasanya dipergunakan juga dimensi uang. Dengan demikian, rencana operasional mudah diukur, peranan keberhasilan unit-unit mudah dibandingkan dan sekaligus dapat 
dijadikan ukuran keberhasilan. Artinya, rencana operasional berfungsi sebagai instrumen yang cukup halus dan tajam untuk mengenali keadaan waktu lampau dan bisa/akan dijadikan alat atau teknik perencanaan berikutnya. Perencanaan operasional bisanya tidak mempergunakan pendekata integratif, seperti halnya renstra. Oleh karena itu, beberapa kelemahan yang ditimbulkan dalam rencana ini, antara lain (1) satuan harga yang tidak pasti, karena sukar merancang harga yang pasti terutama hal-hal yang spesifik, (2) alat ukur sering berbeda-beda, (3) pekerjaan adakalanya tertunda, staf yang berhenti; (4) peranan dan konstribusi pemimpin terhadappencapaian tujuan jangka panjang tidak diukur. Kesemua itu merupakan hambatan-hambatan sistema (Fattah, 2008: 58-59).

Perencanaan operasional disebut juga sebagai perencanaan jangka pendek. Perencanaan jangka pendek adalah perencanaan tahunan atau perencanaan yang dibuat untuk dilaksanakan dalam waktu kurang dari 5 tahun, sering disebut sebagai rencana operasional.

Perencanaan ini merupakan penjabaran dari rencana jangka menengah dan jangka panjang. Perencanaan tahunan termasuk kategori perencanaan jangka pendek. Perencanaan tahunan atau Anual Planning merupakan tahap-tahap dari repelita. Suatu perencanaan tahunan umumnya mempunyai kaitan yang erat dengan apa yang telah dilakukan pada tahun yang lalu dan yang direncanakan pada tahun berikutnya.

Dengan demikian, perencanaan tahunan bukan hanya sekedar pembabakan dari rencana lima tahun, tapi merupakan penyempurnaan dari rencana itu sendiri.

Kegiatan perencanaan tahunan yang dilakukan setiap tahun berlangsung selama satu tahun penuh. Itulah sebabnya ada istilah siklus (lingkaran) perencanaan tahunan. Pelaksanaan rencana dalam pelita dimulai 1 April sampai dengan 31 Maret pada tahun berikutnya. Periode ini berlaku juga bagi penyelesaian proses perencanaannya.

Kegiatan-kegiatan apakah yang terdapat dalam penyusunan rencana tahunan? Secara garis besar jenis kegiatan dan tahapannya dapat dilihat dalam contoh kegiatan tahun 1990-an, meliputi sebagai berikut:

1. Penyusunan kebijaksanaan umum

2. Penyusunan kebijaksanaan teknis.

3. Penyusunan rancangan penyesuaian kebijaksaan.

4. Penyempurnaan program (Reprograming)

5. Penyusunan uraian kegiatan operasional proyek-proyek (UKOP).

6. Identifikasi proyek.

7. Penyusunan Pra-DUP (Daftar Usulan Proyek).

8. Penyusunan DUP Depdikbud.

9. Pembahasan DUP, antara Depdikbud, Bappenas dan Departemen Keuangan (cq.Direktorat Jendral Anggaran).

10. Penyusunan UKOP. 
11. Penyusunan Pra-DIP (Daftar Isian Proyek)

12. Pembahasan Pra-DIP, antara Depdikdud, Bappenas dan Dirjen Anggaran.

13. Penyempurnaan UKOP

14. Penyelesaian DIP dari konsep DIP yang telah disetujui (Fattah, 2008: 60-61).

Pertanyaan mendasar yang perlu mendapat jawaban adalah mengapa manajemen strategik dan manajemen operasional dibutuhkan dalam semua proses dan aktivitas organisasi, termasuk dalam lembaga pendidikan?

Setiap organisasi pasti diperhadapkan pada dua jenis lingkungan yaitu lingkungan internal dan lingkungan eksternal. Semakin besar suatu organisasi, maka makin kompleks pula bentuk, jenis dan sifat jangkauan interaksinya. Salah satu implikasi dari kompleksitas itu adalah semakin sulitnya pemimpin organisasi dalam mengambil kebijakan, apalagi setiap pemimpin memiliki tipe yang berbedabeda. Oleh karena itu manajemen strategik dan manajemen operasional dibutuhkan untuk menemukan solusi yang cepat dan tepat.

Manajemen strajetejik dan manajemen operasional sangat dibutuhkan oleh semua organisasi dalam berproses dan beraktivitas, karena tanpa keduanya, semua usaha dalam rangka mencapai tujuan yang telah ditetapkan akan mengalami kegagalan, minimal tujuan itu tak akan tercapai secara maksimal. Hani Handoko (1998: 6-7) memberikan tiga alasan utama mengapa manajemen itu dibutuhkan dalam setiap organisasi, yaitu:

1. Untuk mencapai tujuan. Dengan penerapan manajemen yang baik, maka pencapaian tujuan organisasi dan perorangan akan lebih mudah tercapai, sebab dengan manajemen kegiatan organisasi diproses secara sistematis mulai tahapan perencanaan, pengorganisasian, kepemimpinan, pengontrolan, hingga penilaian.

2. Untuk menjaga keseimbangan di antara tujuan yang saling bertentangan. Manajemen dibutuhkan untuk menjaga keseimbangan antara berbagai tujuan, sasaran, kegiatan pembagian tugas, pembiayaan dan lain-lain.

3. Untuk mencapai efisiensi dan efektivitas. Suatu pekerjaan dan aktivitas organisasi dapat diukur dengan berbagai pendekatan dan cara. Ukuran yang umum dipakai adalah standar efisiensi dan efektivitas.

Maka urgensitas manajemen strategik dan manajemen operasional dalam kerangka membangun suatu organisasi, perusahaan maupun lembaga menjadi solid, mapan dan kuat di tengah terpaan berbagai tantangan, terutama persaingan global. Dengan menggunakan Manajemen Strategik dan manajemen operasional, sebagai suatu kerangka kerja (framework) untuk mencapai tujuan yang strategis yang telah ditetapkan organisasi atau perusahaan, terutama berkaitan dengan persaingan, maka para pimpinan/manajer diajak untuk berfikir secara strategik.

Ada beberapa sifat yang selalu melekat pada Manajemen Strategik dan manajemen operasional dalam pencapaian tujuan lembaga pendidikan, yaitu: 
1. Unified, yaitu menyatukan seluruh unsur dalam organisasi, lembaga atau perusahaan.

2. Comprehensive, yaitu menyeluruh, mencakup seluruh aspek dalam organisasi, lembaga atau perusahaan.

3. Integrated, yakni seluruh strategi menyatu dan cocok dengan keseluruhan posisi dan tingkatan (Agustinus Sri Wahyudi, 1996: 16).

Lalu sejauh mana urgensitas dan manfaat bagi lembaga pendidikan, jika dalam pencapaian suatu tujuan menerapkan manajemen strategik dan manajemen operasional, Agustinus Sri Wahyudi (1996: 16) memaparkan manfaat itu adalah:

1. Memberikan arah jangka panjang terhadap upaya pencapaian tujuan.

2. Membantu suatu lembaga pendidikan beradaptasi dengan berbagai perubahan yang terjadi.

3. Membuat suatu lembaga pendidikan menjadi lebih efektif.

4. Aktivitas pembuatan strategi akan mempertinggi kemampuan lembaga pendidikan untuk mencegah munculnya masalah di masa datang.

5. Keterlibatan para guru/staf/pegawai dalam menyusun strategi akan mendongkrak motivasi mereka dalam pelaksanaannya.

6. Pembagian tugas yang tumpang tindih akan terminimalisir.

7. Keengganan dan kebosanan para guru/staf/pegawai dalam bekerja akan hilang.

Sebenarnya, diakui atau tidak, ketujuh hal tersebut merupakan permasalahan kronis yang selalu dihadapi oleh lembaga pendidikan yang dalam operasional aktivitasnya masih menggunakan pendekatan konvensional yaitu pencapaian tujuan jangka panjang belum terarah, lembaga pendidikan kurang tanggap terhadap perubahan di sekitarnya, pelaksanaan program terkadang tidak efektif dan efisien, kepala sekolah kurang memberi prioritas pada gejala ketidakberesan yang muncul sehingga banyak masalah yang muncul di kemudian hari karena tidak terdeteksi, para guru dan staf tidak dilibatkan dalam penyusunan strategi, pembagian tugas sering tumpang tindih antara satu pegawai dengan lainnya, dan secara psikologis para pegawai terkadang cepat bosan dalam melakukan pekerjaan.

Manajemen sering dipandang sebagai suatu cara untuk mengendalikan organisasi secara efektif dan efisien, sampai kepada tahap implementasi dan evaluasinyanya sedemikian rupa, sehingga tujuan dan sasarannya tercapai. Sedangkan konsep-konsep manajemen strategik dan manajemen operasional sendiri selalu memberi perhatian serius terhadap perumusan tujuan dan sasaran organisasi, faktor-faktor yang menjadi kekuatan dan kelemahannya, serta peluangpeluang dan tantangan yang senantiasa dihadapi oleh setiap organisasi. Analisis mengenai faktor-faktor ini sangat berguna dalam merumuskan alternatif-alternatif yang akan memudahkan para pengambil keputusan terutama kepala sekolah dalam setiap memilih alternatif terbaik. Setelah memperhitungkan konsekuensi- 
konsekuensi yang akan timbul apabila salah satu alternatif dipilih dan dilakasanakan.

Oleh sebab itu, tidak dapat dihindari bahwa dimensi-dimensi utama dalam konsep manajemen strategik dan manajemen operasional saling berkaitan satu dengan yang lain, saling menjalin, sehingga apabila seseorang hendak berbicara tentang keputusan strategik, ia tidak dapat menghindari pembahasan tentang prinsip-prinsip utama dalam manajemen operasional. Sebab strategi didesain untuk menghasilkan perilaku kepemimpinan dan menghasilkan pemimpin yang dapat memberikan inspirasi melalui visi dan misinya.

Apabila pengambilan keputusan dalam manajemen strategik yang merupakan fungsi manajemen, begitu pula peranan manajemen operasional lebih bersifat pada bagaimana implementasi keputusan tersebut di lapangan atau pelaksanaan teknisnya. Sementara itu, manajemen strategik memantau dan menggerakan aktivitas operasional dari semua pihak yang bertanggung jawab dan yang terlibat dalam mencapai tujuan dan sasaran organisasi.

Salah satu contoh yang dapat dilakukan dalam implementasi manajemen strategik dan manajemen operasional di lembaga pendidikan khususnya lembaga pendidikan Islam seperti madrasah dan pondok pesantren adalah mencanangkan empat program strategis, yaitu (1) Peningkatan mutu manajemen pendidikan, (2) Peningkatan kualitas pendidikan kepesantrenan dan tahfidz Alquran, (3) Peningkatan kompetensi tenaga kependidikan, (4) Program Perkampungan Bahasa (Arab dan Inggris), (5) Program ketrampilan hidup (life skill). Menurut Drs. K.H. Thahir Syarkawi bahwa sasaran yang ingin dicapai dari strategi itu antara lain (a) terwujudnya pendidikan yang efektif yang ditopang tenaga kependidikan yang memenuhi standar kompetensi; (b) santri menguasai pengetahuan keislaman dan mengamalkannya dalam kehidupan sehari-hari, (c) santri dapat berbahasa dan berkomunikasi bahasa Arab dan Inggris secara aktif, (d) santri memiliki pengetahuan dan ketrampilan dasar teknologi pertanian, peternakan dan konveksi (menjahit) dan lain-lain.

Untuk itu, menurut Salusu J. (1996: 498) ada lima hal yang perlu ditekankan dalam mengimplementasikan manajemen strategik dan manajemen operasional dalam meningkatkan mutu pendidikan di sebuah lembaga pendidikan, dalam menghadapi tantangan global yaitu:

a. Peningkatan kualitas manajemen pendidikan

b. Peningkatan kualitas poses pembelajaran

c. Peningkatan kualitas SDM tenaga kependidikan

d. Membangun jaringan kerja (networking).

Manajemen strategik dan manajemen operasional harus dipandang sebagai proses untuk mendorong kemauan belajar dan bertindak, tidak semata-mata sebagai satu sistem formal untuk melakukan pengendalian. Oleh karena itu, penggunaan dan pemanfaatan manjemen strategik dan manajemen operasional 
yang tepat dapat memberikan petunjuk bagaimana mengatasi masalah-masalah dan peluang di masa yang akan datang. Di samping itu akan dapat mempercepat pengambilan keputusan dan pelaksanaan teknisnya dengan lebih baik dan bermutu.

\section{PENUTUP}

Berdasarkan uraian penulis sebelumnya, dapat dikemukakan kesimpulan sebagai berikut:

1. Manajemen strategik adalah serangkaian usaha, kiat, keputusan dan tindakan yang mendasar yang digariskan oleh pimpinan organisasi dan diimplementasikan oleh seluruh jajarannya dalam rangka mencapai tujuan yang telah ditetapkan oleh organisasi itu. Sedangkan manajemen operasional meliputi pengelolaan dalam aspek pengadaan tenaga kerja (procurement), pengembangan (development), kompensasi, integrasi, (integration), pemeliharaan (maintenance) dan pemutusan hubungan kerja (separation).

2. Implementasi manajemen strategik dan manajemen operasional pada lembaga pendidikan dapat memberikan dampak positif pada pengembangan lembaga pendidikan dengan memberikan petunjuk tentang mengatasi masalah-masalah dan peluang pada saat sekarang dan di masa yang akan datang, serta akan mengakuratkan pengambilan keputusan dan pelaksanaan teknisnya secara lebih baik.

\section{DAFTAR PUSTAKA}

Ahmed, Akbar S. dan Hastings Donnan, Islam, Globalization and Posmodernity. London: Routledge, 1994.

Alkalali, As'ad M. Kamus Indonesia - Arab. Jakarta: Bulan Bintang, 1987.

Azizi, A. Qodri. Melawan Globalisasi Reinterpretasi Ajaran Islam. Jakarta: Pustaka Pelajar, 2003.

Burhanuddin. Analisis Administrasi Manajemen dan Kepemimpinan Pendidikan. Jakarta: Bumi Aksara, 1994.

Flippo, Edwin B. Personal Management, diterjemahkan oleh Moh. Masud dengan Judul : Manajemen Personalia. Jilid I; Jakarta: Erlangga, 1996.

Freeman, R. Edward. Strategic Management A Stakeholder Approach. Edisi Indonesia. Jakarta: Pustaka Binaman Presindo, 1996.

Handoko, T. Hani. Manajemen, Edisi 2, Yogjakarta: BPFE, 1998.

J. Salusu, Pengambilan Keputusan Strategik Untuk Organisasi Publik dan Non Provit. Jakarta : PT. Gramedia, 1996.

Nata, Abuddin. Manajemen Pendidikan Mengatasi Kelemahan Pendidikan Islam di Indonesia. Jakarta: Prenada Media, 2003.

Nawawi, Hadari. Manajemen Strategik Organisasi Non-Profit Bidang Pemerintahan. Jogjakarta: Gajah Mada University Press, 2003. 
Siagian, Sondang P. Manajemen Strategik. Jakarta: Bumi Aksara, 2001.

Taylor, Ralph. Websters's World University Dictionary. Washington: Publishers Company, 1965.

Wahyudi, Agustinus Sri. Manajemen Strategik. Jakarta: Binarupa Aksara, 1996

Willy, Markus dkk., Kamus Lengkap Plus Inggris - Indonesia, Indonesia Inggris. Surabaya: Arkola, 1997. 